\title{
TEXT MESSAGING ETIQUETTE: AN EXPLORATION OF SOCIAL BREACHES
}

\author{
Jennifer Breese-Vitelli, Middle Georgia State College, jennifer.breesevitel@mga.edu \\ Philip Kim,Walsh University, pkim@walsh.edu \\ C. Kay Jenkins, Lasell College, CJenkins@lasell.edu
}

\begin{abstract}
The usage of mobile devices and more specifically the usage of text messages in various social situations is most prevalent among young adults, some of which may be considered by some as a social breach; more specifically, the practice of texting while engaged in a face-to-face conversation either directly or while in a public setting with others, which results in the inattention to the immediate social environment. Just as technology is changing, societal norms for methods of communication and information among young adults are also changing. Text messages are used as a medium to maintain relationships, but they can also be used as a means to perpetuate what would be considered deviant behavior with regard to societal norms.
\end{abstract}

Keywords: Texting, Etiquette, Social Media, Ethics

\section{INTRODUCTION}

Text messages were not originally thought of as a medium that would that would become a dominant trend among young people. The phone call itself seemed like it would be the ultimate intended goal for communication; but, through a combination of actors, companies, previous technologies, etcetera a collective process of interacting parts lead to the development of SMS messaging into the ubiquitous form of communication it is today. And college-age participants place a great deal of importance on texting [7]. Technological innovations which involved the mobile phone began as early as the 1940's but the boon for the technology did not occur until the 1990's [17]. The idea of associating cellular phones solely with mobility has been changed by young people who have transformed the definition of mobility. Youth have been observed using cellular phones in close proximity to one another including while they are in the same room $[9 ; 16 ; 18]$. Research has shown that the impersonal dialogue of a cell phone screen appears to trump the immediate social and physical environment of texters and may allow the user to feel relaxed social culpability $[7 ; 18]$. A prolonged period of such social breaches can affect interaction and communication skills in this age group.

\section{LITERATURE REVIEW}

The 160 character limit and the multi-tap method for typing text messages led young people to explore and adapt their communication styles to a hybrid style that became a new linguistic form of communication. However, the use of mobile telephones in various situations has become an element in the definition of socially appropriate/inappropriate behavior [11]. Young adults stand far above all other demographic groups when it comes to their usage of text messaging [16]. A full 95 percent of 18-29 year olds use the text messaging feature on their phones, and these users send or receive an average of 87.7 text messages on a normal day (with the median user in this age group sending or receiving 40 text messages per day) [16].

Pew Research Center (2012), it was found that texting is nearly universal among young adults, ages 18-29, and 97 percent use texting [3]. Despite an explosion in the popularity of text messaging, little research has documented the prevalence of its use in various dimensions of the social landscape of young adults [7]. An examination was conducted of where people place the boundary between the appropriate and the inappropriate use of mobile telephones; however, little has been studied in the manner of the young adult age group and their text messaging practices with regard to appropriateness in the social setting [11].

In a study concerning the behavior of new cell phone users, it was found that it was not uncommon for subjects to have thought about how and when they would use their mobile phones in public places [14]. Given that young adults are predominant users of text messages, speculation has arisen that text messaging could negatively impact social skills in individuals who use it too frequently, as it seems that one becomes socially removed from one's immediate environment when engaging in texting, rejecting one's surrounding social obligations and opportunities for those electronically presented on the tiny screen of a cell phone [7; 18]. 


\section{Issues in Information Systems \\ Volume 15, Issue II, pp. 157-167, 2014}

Communications patterns are shifting among teens as their array of options grows [10]. In relation to teenage text usage, it was found that being in a public place was the most frequent context for sending a text message [4]. Thurlow (2003) revealed that only one-third of text messages accomplished a task, so what are they doing? With such a profound presence in contemporary society, understanding the social parameters of this communication medium is an important endeavor [15] as well as investigating the appropriateness in social contexts of young adults and the effect it may have on interpersonal relationships. Helsel (2008) studied the influence of technology on adolescent development; she contended that the introduction of new technologies influences culture and in turn the way adolescents communicate and develop relationships. An exploration of the influence cell phone technology has had on teen development might reveal their use or misuse of the technology [8].

Since texting is an asynchronous activity, users need not be actively engaged with one another when communicating; it can be done while engaging in other activity and this can create challenges in interpersonal encounters. When it comes to text messaging, the synchronization of actions and the development of norms within a given culture are still being discovered. When in use, mobile phones occupy multiple social spaces simultaneously, spaces with norms that sometimes conflict: the physical space of the mobile phone user and the virtual space of the conversation [16].

A university study was conducted to argue that the use of text messaging by university staff would ease the transition process for undergraduate students. The study found that students that experience wider social networks are crucial to transition and text messaging is a key factor in maintaining those social networks [6.] But, is there also a price to be paid for maintaining these larger social networks simultaneously? A potential motivation for texting inappropriately in social contexts among young adults may be identified with a concern of controlling social outcomes. The receivers of text messages may feel anxious to respond immediately to the information received because of a belief that failure to respond within an appropriate time frame may unintentionally indicate his/her indifference toward a sender [11].

Again, who determines the appropriateness of sending text messages in historically inappropriate settings? Some technologies can have positive effect as long as a change also occurs in society. Change is possible if a political and socio-change occurs hand in hand with new technology [5]. Therefore, changes in the determination of the appropriateness of the behavior in certain demographics and or cultural cohorts could be occurring.

\section{RESEARCH QUESTIONS}

This study proposed to exploration the practices of young adults aged 18 to 29 in terms of text messaging via mobile devices in various social contexts including those to be considered a breach of social norms.

The following research questions with regard to the 18 to 29 aided in the exploration:

RQ1: How often do young adults use text messaging?

RQ2: How often do young adults participate in text messaging as a social breach?

RQ3: Do young adults consider such social breaches to be rude?

RQ4: What is the likelihood that young adults would contribute to a social breach through the usage of text messaging?

\section{METHODOLOGY}

\section{Survey}

The quantitative method administered provided correlations rather than predictive means $[1 ; 11]$. Therefore, the intended result of the correlations was not to prove a causal, but rather to show a direct relationship. The quantitative method provided the ability to draw generalizations about the population by taking a sample of that population and formulating claims based on the results. A quantitative research strategy conducted via survey questionnaire and consisting of 32 questions was used to gather information. The data collected was analyzed in terms of frequency regarding general text message usage within this age group and the correlation between social 
breaches; in addition, the measure of agreement, or lack of, in regard to whether the situations examined are considered to be a breach of the given context.

Study participants and plan of execution. The sample used in this research included young adults aged 18 to 29 . The survey questions used were organized to further indicate gender, as well as comparison of the lower end of the age group to the higher end with the split being ages 18 to 23 contrasted with ages 24 to 29; both groups equally consisting of six ages. The participants were recruited from a social media network posting that contains a link to the survey questionnaire. A snowball sampling technique was employed through the request to share the survey with others known to be within the targeted population.

\section{Survey Results}

A survey was administered to analyze the usage of text messaging among American young adults, more specifically, when text messaging was used in a social context and considered to be a social breach. The study not only explored when the young adults engaged in a social breach with text messaging usage, but also how they felt about the practice and whether or not they considered it to be an inappropriate practice with regard to their own habits, as well as others. Additional discovery was attempted to analyze if there was a difference in mindset based on whether they were committing the social breach as opposed to others committing the social breach around them.

\section{Participants}

The data was gathered through a snowball sampling on social media, specifically Facebook, the survey remained active for a one week period. The survey was administered through a posted link on the profile pages of three young adults in the desired age demographic. The one week posting, without reposts, produced 17 responses.

\section{Results}

Table 1. Statistical Data of Participants and General Text Messaging Habits

\begin{tabular}{|l|c|c|}
\hline Q1. Age group & Frequencies & Percentages \\
\hline Ages 18-23 & 7 & $41 \%$ \\
\hline Ages 24-29 & 10 & $59 \%$ \\
\hline
\end{tabular}

\begin{tabular}{|l|c|c|}
\hline Q2. Gender & Frequencies & Percentages \\
\hline Female & 11 & $65 \%$ \\
\hline Male & 6 & $35 \%$ \\
\hline
\end{tabular}

\begin{tabular}{|l|c|c|}
\hline Q3. How often do you communicate through text messaging? \\
\hline & Frequencies & Percentages \\
\hline Rarely & 0 & $0 \%$ \\
\hline Occasionally & 1 & $6 \%$ \\
\hline Frequently (not every day) & 3 & $18 \%$ \\
\hline Every day & 13 & $76 \%$ \\
\hline
\end{tabular}

In this random sampling, the upper end of the young adult age category was more represented with (59\%) participation compared to (41\%) in the lower end age category. The female population made a stronger contribution with eleven participants, in contrast to only six male participants. However, the overall population of the sampling showed that the majority of young adults use text messaging to communicate with (76\%) reported usage every day; (18\%) reported frequent usage; and one person (6\%) reported occasional use of text messaging; none of the sampling reported usage as rare. 
Table 2. Usage of Text Messaging During a Face-to-Face Conversation

\begin{tabular}{|l|c|c|}
\hline \multicolumn{3}{|c|}{ Q4. Have you ever text messaged while engaged in a face-to-face conversation? } \\
\hline & Frequencies & Percentages \\
\hline Yes & 12 & $71 \%$ \\
\hline No & 5 & $29 \%$ \\
\hline
\end{tabular}

Q5. How likely are you to text while engaged in a face-to-face conversation?

\begin{tabular}{|l|c|c|}
\hline & Frequencies & Percentages \\
\hline Never & 2 & $12 \%$ \\
\hline Rarely & 8 & $47 \%$ \\
\hline Occasionally & 6 & $35 \%$ \\
\hline Frequently & 1 & $6 \%$ \\
\hline
\end{tabular}

Q6. In the past week, how many text messages have you sent or received while engaged in a face-to-face conversation?

\begin{tabular}{|l|c|c|}
\hline & Frequencies & Percentages \\
\hline None & 2 & $12 \%$ \\
\hline $1-10$ & 11 & $64 \%$ \\
\hline $11-20$ & 2 & $12 \%$ \\
\hline $21-30$ & 0 & $0 \%$ \\
\hline $31-40$ & 1 & $6 \%$ \\
\hline $41-50$ & 0 & $0 \%$ \\
\hline $50+$ & 1 & $6 \%$ \\
\hline
\end{tabular}

Q7. Level of agreement: It is rude to engage in text messaging during a face-toface conversation.

\begin{tabular}{|l|c|c|}
\hline & Frequencies & Percentages \\
\hline Strongly disagree & 0 & $0 \%$ \\
\hline Disagree & 0 & $0 \%$ \\
\hline Neither agree nor disagree & 4 & $24 \%$ \\
\hline Agree & 7 & $41 \%$ \\
\hline Strongly agree & 6 & $35 \%$ \\
\hline
\end{tabular}

\section{Q27. Level of agreement: I feel offended when someone is text messaging while I} am talking to them in a face-to-face conversation.

\begin{tabular}{|l|c|c|}
\hline & Frequencies & Percentages \\
\hline Strongly disagree & 1 & $6 \%$ \\
\hline Disagree & 5 & $29 \%$ \\
\hline Neither agree nor disagree & 2 & $12 \%$ \\
\hline Agree & 6 & $35 \%$ \\
\hline Strongly agree & 3 & $18 \%$ \\
\hline
\end{tabular}

When the young adults were asked whether or not they had ever participated in the practice of text messaging during a face-to-face conversation, the majority answered yes with (71\%); whereas, only (47\%) reported a likelihood that they would engage in this practice. This difference might be explained in the reported number of text messages sent or received in the past week during a face-to-face conversation; the majority, at (64\%), reported a range of one to ten for text message usage while engaged in a face-to-face conversation. Even though most had shared that they had participated in the practice, the number of text messages sent or received was low; therefore, making the practice unlikely. 
Despite the majority of young adults admitting that they have engaged in the practice of text messaging during a face-to-face conversation, they also reported that they find the practice to be rude ( $41 \%$ agree, $35 \%$ strongly agree); and $(35 \%)$ feel offended when someone they are having a face-to-face conversation with engages in text messaging.

Table 3. Usage of Text Messaging During a Movie in a Public Theater

\begin{tabular}{|l|c|c|}
\hline \multicolumn{3}{|c|}{ Q8. Have you ever text messaged during a movie at a public theater? } \\
\hline & Frequencies & Percentages \\
\hline Yes & 10 & $59 \%$ \\
\hline No & 7 & $41 \%$ \\
\hline
\end{tabular}

\begin{tabular}{|l|c|c|}
\hline \multicolumn{3}{|c|}{ Q9. How likely are you to text during a movie at a public theater? } \\
\hline & Frequencies & Percentages \\
\hline Never & 5 & $29 \%$ \\
\hline Rarely & 11 & $65 \%$ \\
\hline Occasionally & 1 & $6 \%$ \\
\hline Frequently & 0 & $0 \%$ \\
\hline
\end{tabular}

Q10. At the last movie you watched in a public theater, how many text messages did you sent/receive during the movie?

\begin{tabular}{|l|c|c|}
\hline & Frequencies & Percentages \\
\hline None & 9 & $53 \%$ \\
\hline $1-10$ & 7 & $41 \%$ \\
\hline $11-20$ & 1 & $6 \%$ \\
\hline $21-30$ & 0 & $0 \%$ \\
\hline $31-40$ & 0 & $0 \%$ \\
\hline $41-50$ & 0 & $0 \%$ \\
\hline $50+$ & 0 & $0 \%$ \\
\hline
\end{tabular}

Q29. Level of agreement: I get annoyed when someone is text messaging during a movie at a public theater.

\begin{tabular}{|l|c|c|}
\hline & Frequencies & Percentages \\
\hline Strongly disagree & 2 & $12 \%$ \\
\hline Disagree & 3 & $18 \%$ \\
\hline Neither agree nor disagree & 5 & $28 \%$ \\
\hline Agree & 3 & $18 \%$ \\
\hline Strongly agree & 4 & $24 \%$ \\
\hline
\end{tabular}

The results were divided on the practice of text messaging while watching a movie at a public theater with (59\%) reported in the affirmative and (41\%) reported in the negative. There was consistency with the reported $(65 \%)$ likelihood of rare usage and an overwhelmingly small amount of text messages being reported in regard to the last movie watched in a public theater with (53\%) stating none and (41\%) stating only one to ten.

With regard to being annoyed by someone else text messaging during a movie, the majority reported no concern with $(28 \%)$ choosing to neither agree nor disagree, followed by a close (24\%) sharing that they do feel annoyed; the remaining category selections were distributed fairly evenly and therefore inconclusive. 
Table 4. Usage of Text Messaging While Dining at a Restaurant

\begin{tabular}{|l|c|c|}
\hline \multicolumn{3}{|c|}{ Q11. Have you ever text messaged while dining with someone at a restaurant? } \\
\hline & Frequencies & Percentages \\
\hline Yes & 15 & $88 \%$ \\
\hline No & 2 & $12 \%$ \\
\hline
\end{tabular}

Q12. How likely are you to text while dining with someone at a restaurant?

\begin{tabular}{|l|c|c|}
\hline & Frequencies & Percentages \\
\hline Never & 2 & $12 \%$ \\
\hline Rarely & 9 & $53 \%$ \\
\hline Occasionally & 4 & $23 \%$ \\
\hline Frequently & 2 & $12 \%$ \\
\hline
\end{tabular}

Q13. During a one-hour meal with someone in a restaurant, how many text messages have you send/receive on average?

\begin{tabular}{|l|c|c|}
\hline & Frequencies & Percentages \\
\hline None & 2 & $12 \%$ \\
\hline $1-10$ & 14 & $82 \%$ \\
\hline $11-20$ & 0 & $0 \%$ \\
\hline $21-30$ & 0 & $0 \%$ \\
\hline $31-40$ & 0 & $0 \%$ \\
\hline $41-50$ & 0 & $0 \%$ \\
\hline $50+$ & 1 & $6 \%$ \\
\hline
\end{tabular}

Q14. Level of agreement: It is rude to engage in text messaging while dining with someone at a restaurant.

\begin{tabular}{|l|c|c|}
\hline & Frequencies & Percentages \\
\hline Strongly disagree & 0 & $0 \%$ \\
\hline Disagree & 2 & $12 \%$ \\
\hline Neither agree nor disagree & 8 & $47 \%$ \\
\hline Agree & 3 & $18 \%$ \\
\hline Strongly agree & 4 & $23 \%$ \\
\hline
\end{tabular}

Q28. Level of agreement: I feel offended when someone is text messaging while I am dining with them at a restaurant.

\begin{tabular}{|l|c|c|}
\hline & Frequencies & Percentages \\
\hline Strongly disagree & 2 & $12 \%$ \\
\hline Disagree & 7 & $41 \%$ \\
\hline Neither agree nor disagree & 1 & $6 \%$ \\
\hline Agree & 4 & $23 \%$ \\
\hline Strongly agree & 3 & $18 \%$ \\
\hline
\end{tabular}

Engaging in text messaging while dining with someone at a restaurant appears to be common with $(88 \%)$ reported that they have engaged in the practice; however, $(53 \%)$ stated that the likelihood is rare, which may be explained by the corresponding data that during a one-hour meal period an overwhelming majority of (82\%) report that they send or receive only one to ten text messages on average.

In regard to viewing the practice as rude when the person they are dining with engages in text messaging, the majority, at (47\%), choose to neither agree nor disagree, showing little concern; whereas the feeling of being offended was fairly evenly split with disagreement of being offended at a combined (53\%) (41\% disagree, $12 \%$ strongly disagree) and agreement of being offended at a combined (41\%) $(23 \%, 18 \%)$. 
Table 5. Usage of Text Messaging During a Religious Service

\begin{tabular}{|l|c|c|}
\hline \multicolumn{3}{|c|}{ Q15. Have you ever text messaged during a religious service? } \\
\hline & Frequencies & Percentages \\
\hline Yes & 6 & $35 \%$ \\
\hline No & 11 & $65 \%$ \\
\hline
\end{tabular}

Q16. How likely are you to text during a religious service?

\begin{tabular}{|l|c|c|}
\hline & Frequencies & Percentages \\
\hline Never & 12 & $70 \%$ \\
\hline Rarely & 4 & $24 \%$ \\
\hline Occasionally & 0 & $0 \%$ \\
\hline Frequently & 1 & $6 \%$ \\
\hline
\end{tabular}

Q17. During a one-hour religious service, about how many text messages have you send/receive on average?

\begin{tabular}{|l|c|c|}
\hline & Frequencies & Percentages \\
\hline None & 12 & $70 \%$ \\
\hline $1-10$ & 4 & $24 \%$ \\
\hline $11-20$ & 1 & $6 \%$ \\
\hline $21-30$ & 0 & $0 \%$ \\
\hline $31-40$ & 0 & $0 \%$ \\
\hline $41-50$ & 0 & $0 \%$ \\
\hline $50+$ & 0 & $0 \%$ \\
\hline
\end{tabular}

Q18. Level of agreement: It is rude to engage in text messaging during a religious service.

\begin{tabular}{|l|c|c|}
\hline & Frequencies & Percentages \\
\hline Strongly disagree & 0 & $0 \%$ \\
\hline Disagree & 0 & $0 \%$ \\
\hline Neither agree nor disagree & 5 & $29 \%$ \\
\hline Agree & 1 & $6 \%$ \\
\hline Strongly agree & 11 & $65 \%$ \\
\hline
\end{tabular}

Q30. Level of agreement: I get annoyed when someone is text messaging during a religious service.

\begin{tabular}{|l|c|c|}
\hline & Frequencies & Percentages \\
\hline Strongly disagree & 0 & $0 \%$ \\
\hline Disagree & 2 & $11 \%$ \\
\hline Neither agree nor disagree & 4 & $24 \%$ \\
\hline Agree & 4 & $24 \%$ \\
\hline Strongly agree & 7 & $41 \%$ \\
\hline
\end{tabular}

Within the areas of social breach examined in this study, the participants showed the most defined view when asked about text messaging habits during religious services; (65\%) said they had never text messaged during a religious service and (70\%) said the likelihood of this practice would be never. A matching (70\%) said that on average they sent zero text messages during a one-hour religious service and (24\%) reported text message usage between one and ten; one person representing the remaining $(6 \%)$, stated a usage of eleven to twenty text messages during a one-hour service, on average.

With regard to viewing the practice as rude, there was zero disagreement; concluding that all participants either shared the view that the practice of text messaging during a religious service was considered rude, or they were not 
concerned with the matter. A (29\%) neither agree nor disagree and a combined agreement of seeing the practice as rude was $(71 \%)(6 \%$ agree, $65 \%$ strongly agree $)$.

Table 6. Usage of Text Messaging While in a Public Speaking Setting

\begin{tabular}{|l|c|c|}
\hline $\begin{array}{l}\text { Q19. Have you ever text messaged while listening to a public speaker? } \\
\text { (classroom, business meeting or other speaking event) }\end{array}$ \\
\hline & Frequencies & Percentages \\
\hline Yes & 16 & $94 \%$ \\
\hline No & 1 & $6 \%$ \\
\hline
\end{tabular}

\begin{tabular}{|l|c|c|}
\hline \multicolumn{3}{|c|}{ Q20. How likely are you to text while listening to a public speaker? } \\
\hline & Frequencies & Percentages \\
\hline Never & 1 & $6 \%$ \\
\hline Rarely & 6 & $36 \%$ \\
\hline Occasionally & 5 & $29 \%$ \\
\hline Frequently & 5 & $29 \%$ \\
\hline
\end{tabular}

Q21. During a one-hour public speaking occasion, about how many text messages have you send/receive on average?

\begin{tabular}{|l|c|c|}
\hline & Frequencies & Percentages \\
\hline None & 1 & $6 \%$ \\
\hline $1-10$ & 10 & $58 \%$ \\
\hline $11-20$ & 4 & $24 \%$ \\
\hline $21-30$ & 1 & $6 \%$ \\
\hline $31-40$ & 1 & $6 \%$ \\
\hline $41-50$ & 0 & $0 \%$ \\
\hline $50+$ & 0 & $0 \%$ \\
\hline
\end{tabular}

Q22. Level of agreement: It is rude to engage in text messaging while listening to a public speaker.

\begin{tabular}{|l|c|c|}
\hline & Frequencies & Percentages \\
\hline Strongly disagree & 1 & $6 \%$ \\
\hline Disagree & 3 & $18 \%$ \\
\hline Neither agree nor disagree & 5 & $29 \%$ \\
\hline Agree & 5 & $29 \%$ \\
\hline Strongly agree & 3 & $18 \%$ \\
\hline
\end{tabular}

Q31. Level of agreement: I get annoyed when someone is text messaging during a public speaking engagement that I am attending.

\begin{tabular}{|l|c|c|}
\hline & Frequencies & Percentages \\
\hline Strongly disagree & 4 & $24 \%$ \\
\hline Disagree & 3 & $18 \%$ \\
\hline Neither agree nor disagree & 6 & $34 \%$ \\
\hline Agree & 2 & $12 \%$ \\
\hline Strongly agree & 2 & $12 \%$ \\
\hline
\end{tabular}

In the matter of text messaging during a public speaking occasion, such as a classroom lecture, a business meeting or other speaking event, the respondents showed heavy usage with a reported (94\%) stated that they have engaged in the practice of text messaging while listening to a public speaker; only one respondent reported that they had never engaged in the practice and also only one respondent reported that is was unlikely. Even though heavy usage was reported, the number of text messages sent or received on average during a one-hour public speaking engagement was low with (58\%) reported one to ten. 
In regard to the view of rudeness when it comes to text messaging while listening to a public speaker, only one respondent strongly disagreed; the remaining data was widely varied leaving no strong conclusion. Likewise, there was significant variation with regard to respondents being annoyed by others engaging in text messaging during a public speaking event and the majority, at (34\%), neither agreed nor disagreed.

Table 7. Usage of Text Messaging During the Checkout Process at a Store

\begin{tabular}{|l|c|c|}
\hline \multicolumn{3}{|c|}{ Q23. Have you ever text messaged during the checkout process at a store? } \\
\hline & Frequencies & Percentages \\
\hline Yes & 10 & $59 \%$ \\
\hline No & 7 & $41 \%$ \\
\hline
\end{tabular}

Q24. How likely are you to text during the checkout process at a store?

\begin{tabular}{|l|c|c|}
\hline & Frequencies & Percentages \\
\hline Never & 6 & $35 \%$ \\
\hline Rarely & 7 & $41 \%$ \\
\hline Occasionally & 2 & $12 \%$ \\
\hline Frequently & 2 & $12 \%$ \\
\hline
\end{tabular}

\section{Q25. Select the statement that you MOST agree with regarding text messaging} during the checkout process at a store.

\begin{tabular}{|l|c|c|}
\hline $\begin{array}{l}\text { It is acceptable to text during the } \\
\text { checkout process for urgent } \\
\text { situations only }\end{array}$ & Frequencies & Percentages \\
\hline $\begin{array}{l}\text { It is acceptable to text during the } \\
\text { checkout process for any reason }\end{array}$ & 6 & $29 \%$ \\
\hline $\begin{array}{l}\text { It is never acceptable to text during } \\
\text { the checkout process, it can always } \\
\text { wait until finished }\end{array}$ & 6 & $35 \%$ \\
\hline
\end{tabular}

\section{Q26. Level of agreement: It is rude to engage in text messaging during the} checkout process at a store.

\begin{tabular}{|l|c|c|}
\hline & Frequencies & Percentages \\
\hline Strongly disagree & 1 & $6 \%$ \\
\hline Disagree & 3 & $18 \%$ \\
\hline Neither agree nor disagree & 4 & $23 \%$ \\
\hline Agree & 8 & $47 \%$ \\
\hline Strongly agree & 1 & $6 \%$ \\
\hline
\end{tabular}

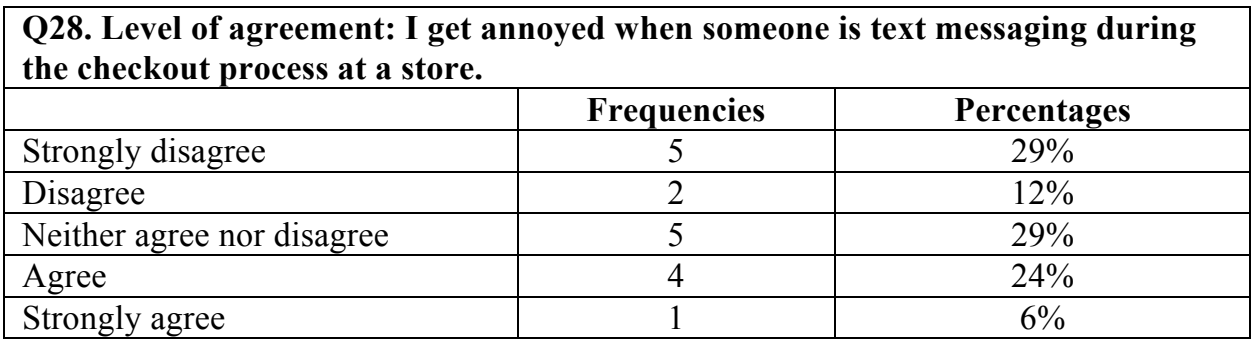

The practice of text messaging during the checkout process at a store was reported to be slightly more frequent with $(59 \%)$ reported that they have engaged in the practice and (41\%) reported that they have not; however, the likelihood was strongly negative with (41\%) stating it would be rare and $(35 \%)$ stating the likelihood was never. The respondents were too closely divided in regard to acceptability of using text messaging during the checkout 
process to make a determination; (35\%) found it acceptable to text message for any reason, while another 35 percent found it never acceptable. The remaining (29\%) reported it to be acceptable only in urgent situations.

The majority of respondents found the practice of text messaging during the checkout process at a store to be rude with $(47 \%)$ agreement and $(6 \%)$ strongly agreeing. With regard to feeling annoyed when someone else engages in text messaging during the checkout process at a store, the results were widely varied and found to be inconclusive.

With future surveys, it would be suggested to narrow the focus and reduce the number of questions, repost numerous times, and utilize the networks of several co-researchers. Additionally, it would be more straightforward in analyzing the results if the number were great allowing for correlations of the variables. Lastly, the use of in-depth qualitative interviews to drill down into the human behaviors is not only appropriate, but necessary for the identification of behavior patterns in differing cohorts.

\section{DISCUSSION}

The use of text messaging can differ greatly based on the individual; there is a wide variety of habits that fluctuate from person to person and influence can come by the variation in setting. In addition, particular circumstances of the subjects being studied can vary from day to day and impact the results; for instance, situations that the participants are facing on a given day can affect the urgent nature of text message usage and decision of usage.

For conclusive results on this topic, it is suggested to conduct the research methods at different points in time to see if the culture norm is shifting and texting as previously determined inappropriate times is now shifting to be part of the norm.

\section{CONCLUSIONS}

It is suggested that "technology is seductive when what it offers meets our human vulnerabilities. ... We are lonely but fearful of intimacy. Digital connections ... offer the illusion of companionship without the demands of friendship. Our networked life allows us to hide from each other, even as we are tethered to each other [14, p. 1]." Meaning is not a neutral method of understanding human behavior. To properly determine texting in terms of deviance from social norms the meaning of the actor should be considered as should the meaning of the act with regard to the peer group that interprets the act as a social interaction. Therefore, what might be considered deviant texting etiquette for one group is part of the cultural norm of another.

\section{REFERENCES}

1. Babbie, E. R. (2010). The practice of social research (12th ed.). Belmont, CA: Thomson Wadsworth.

2. Colbert, M. (2005). Usage and user experience of communication during and before rendezvous. Behaviour \& Information Technology, 449-469.

3. Duggan, M., \& Rainie, L. (2012). Cell Phone Activities 2012. Washington D.C.: Pew Research Center's Internet \& American Life Project.

4. Eldridge, M. \& Grinter, R. (2001). Studying Text Messaging in Teenagers. Position Paper for CHI 2001 Workshop \#1, Mobile Communications: Understanding User, Adoption and Design.

5. Ellul, J. (1990). Ambivalence. Chapter One of The Technological Bluff. Grand Rapids: Eerdmans,35-76.

6. Harley, D., Winn, S., Pemberton, S., \& Wilcox, P. (2007). Using texting to support students' transition to university. Innovation in Education and Teaching International, 44(3), 229-241.

7. Harrison, M. A., \& Gilmore, A. L. (2012). U txt WHEN? College students' social contexts of text messaging. The Social Science Journal, 513-518.

8. Helsel, Stephanie. (2008). The Influence of Technology on Adolescent Development: An Eco-Cultural analysis of Cybersocial Activity

Retrieved from Dissertations and Theses database.(AAT3322174)

9. Lacohee, H., Wakeford, N., \& Pearson, I. (2003). A social history of the mobile telelphone with a view of its future. BT Technology Journal, 21(3), 203-211.

10. Lenhart, A., Madden, M., Smith, A., \& Macgill, A. M. (2007, December 19). Teens and Social Media|Pew Internet \& American Life Project. Retrieved October 4, 2009, from 
http://www.pewinternet.org/Reports/2007/Teens-and-Social-Media.aspx

11. Ling, R. (1997). One can talk about common manners!: the use of mobile phones in inappropriate situations. Themes in mobile telephony Final Report of the COST 248 Home and Workgroup, 1-18.

12. Mahatanankoon, P., \& O'Sullivan, P. (2008). Attitude Toward Mobile Text Messaging: An Expectancy-Based Perspective. Journal of Computer-Mediated Communication, 973-992.

13. Mertler, C. A. (2009). Action research: teachers as researchers in the classroom (2nd ed.). Los Angeles: Sage. 14. Paylen, L., Salzman, M., \& Youngs, E. (2000). Going Wireless: Behavior \& Practice of New Mobile Phone Users. Boulder: University of Colorado.

15. Reid, D. and Reid, F. (2004). Insights into the social and psychological effects of sms text messaging. 16. Smith, A. (2011). Pew Internet and American Life Project. Washington D.C.: Pew Research Center.

17. Taylor, A., \& Vincent, J. (2005). An SMS History. In L. Hamill \& A. Lasen (Ed.), Mobile World: Past, Present and Future (Computer Supported Cooperative Work) (pp. 75-91). New York: Springer.

18. Turkle, S. (2011). Alone together: Why we expect more from technology and less from each other. New York: Basic Books. 